\title{
EVALUASI BAHASA INGGRIS SEBAGAI BAHASA PENGANTAR DALAM PROSES PEMBELAJARAN DI SDN IDAMAN RSBI BANJARBARU
}

\section{EVALUATION OF BILINGUAL INSTRUCTION IN SDN IDAMAN RSBI BANJARBARU}

\author{
Daud Yahya, Suwarjo \\ PPS UNY, Universitas Negeri Yogyakarta \\ cumadaud@gmail.com,suwarjo@uny.ac.id
}

\begin{abstract}
Abstrak
Tujuan dari penelitian ini adalah menggambarkan dan mengevaluasi penerapan Bahasa Inggris sebagai bahasa pengantar dalam proses pembelajaran di SDN Idaman RSBI Banjarbaru. dengan menggunakan evaluasi model Kesenjangan. Data dikumpulkan dengan tiga metode yaitu: interview, observasi dan dokumentasi. Dalam wawancara, peneliti menggali tanggapan, pengalaman dan persepsi guru dan Kepala Sekolah terkait dengan Bahasa Inggris sebagai bahasa pengantar. Dalam observasi, peneliti mengumpulkan data tentang materi dan aktivitas pembelajaran. Dalam dokumentasi, peneliti mengumpul-kan data tentang sekolah dan pembelajaran dari dokumen terkait. Untuk mencapai keterpercayaan, inter-pretasi data diverifikasi kembali oleh guru dan Kepala Sekolah sampai tidak ada pertentangan pandangan terhadap makna data tersebut. Akhirnya, analisa data dituangkan dalam metode kualitatif untuk meng-gambarkan hasil dari pengumpulan data. Hasil penelitian menunjukkan bahwa penggunaan Bahasa Inggris sebagai bahasa pengantar dalam proses pembelajaran di SDN Idaman RSBI Banjarbaru belum terlaksana sepenuhnya sesuai standar yang ada pada Pedoman Pembelajaran Bahasa Inggris di SD Depdiknas 2008.
\end{abstract}

Kata kunci: evaluasi bahasa pengantar

\begin{abstract}
The purpose of this study is to determine and evaluate the implementation of Bilingual instructions in SDN Idaman RSBI Banjarbaru. This research was a model of Discrepancy evaluation research. The data were collected through three methods: interview, observation and documentation. In the interview, the researcher tried to find out teacher's and headmaster's responses, experiences, opinion/perception related to the English teacher-talk at SDN Idaman RSBI Banjarbaru. In the observation, the researcher gathered teaching materials and teaching activities to see whether or not they included bilingual instruc-tions in their lesson plans and learning activities. In documentation, the researcher collected data about school and learning activities from related document. To achieve trustworthiness, the data interpretation from researcher were verified by teachers and the headmaster until there was no different perspective about it. Finally, data analysis was done by qualitative method to illustrate the results of the data collec-tion. The results show that the use of bilingual instructions in each lesson is applied imperfectly.
\end{abstract}

Keywords: bilingual instructions evaluation. 


\section{Pendahuluan}

SDN Idaman RSBI sebagai satuan pendidikan bertaraf internasional, mendasarkan penyelenggaraannya kepada Panduan Penyelenggaraan Sekolah Bertaraf Internasional (2007) yang diterbitkan oleh Direktorat Jenderal Manajemen Pendidikan Dasar dan Menengah yang menyebutkan bahwa bahasa asing (dalam hal ini Bahasa Inggris) tercantum dalam UUSPN No. 20 Tahun 2003. Penggunaan bahasa asing ini juga didorong pelaksanaannya oleh Departemen Pendidikan Nasional. Dirjen Manajemen Pendidikan Dasar dan Menengah Depdiknas pada sebuah kesempatan mengatakan "....secara bertahap Depdiknas akan menganjurkan sekolah-sekolah untuk mulai menggunakan bahasa pengantar Inggris untuk mata pelajaran tertentu seperti Matematika dan Sains."(http://berita.kapanlagi.com/ pernik/depdiknas-akan-dorong-penguasaanbahasa-inggris-rg9lei9.html)

Masih menurut UUSPN No. 20 Tahun 2003 Pasal 57 ayat 1, evaluasi dilakukan dalam rangka pengendalian mutu pendidikan secara nasional sebagai bentuk akuntabilitas penyelenggara pendidikan kepada pihak-pihak yang berkepentingan di antaranya peserta didik, lembaga, dan program pendidikan. Pada ayat selanjutnya, ditegaskan lagi bahwa evaluasi dilakukan terhadap peserta didik, lembaga dan program pendidikan pada jalur formal dan nonformal untuk semua jenjang satuan dan jenis pendidikan. Evaluasi terhadap kegiatan pembelajaran ini tidak hanya bisa dilakukan oleh kalangan peneliti akademis dan/atau evaluator saja, guru pun dalam hal ini mempunyai tanggung jawab dan hak yang sama seperti yang dijabarkan dalam UUSPN No. 20 Tahun 2003 Pasal 58 ayat 1 bahwa evaluasi hasil belajar peserta didik dilakukan oleh pendidik untuk memantau proses, kemajuan dan perbaikan hasil belajar peserta didik secara berkesinambungan.

Dari sudut pandang guru, evaluasi bukan hanya menjadi bagian dari amanat undangundang, akan tetapi juga mempunyai manfaat sebagai feedback yang bersumber langsung dari kegiatan belajar mengajar. Evaluasi pembelajaran sebenarnya adalah bagian yang tidak terpisahkan dari kegiatan mengajar, karena melalui evaluasi seorang guru tidak hanya akan mendapat masukan tentang pencapaian hasil belajar akan tetapi juga akan mengetahui apakah materi, metode dan teknik mengajar yang dijalankannya benar-benar sesuai dengan tujuan yang ditentukan sebelumnya. Jika kurang berhasil, maka guru akan memperbaiki kekurangannya, sebaliknya bila sudah sesuai dengan yang direncanakan maka akan dipertahankan dan/atau ditingkatkan lagi kualitasnya.

Pembelajaran bahasa Inggris dan penerapan bahasa Inggris sebagai bahasa pengantar dalam proses pembelajaran adalah dua hal yang berbeda. Pembelajaran bahasa Inggris adalah kegiatan pembelajaran yang mengupas tentang bahasa Inggris sebagai suatu bahasa, sedangkan penerapan bahasa Inggris sebagai bahasa pengantar dalam pembelajaran adalah bagaimana instruksi-instruksi dalam kegiatan belajar mengajar disampaikan dalam bahasa Inggris. Walaupun berbeda, kedua hal tersebut menganut prinsip yang sama yaitu bahasa Inggris yang digunakan adalah bahasa Inggris yang sederhana sesuai dengan tingkat pemahaman dan kebutuhan, serta diberikan secara berulang-ulang dengan prinsip penguatan dengan tujuan agar siswa bisa berkomunikasi secara sederhana dalam lingkup sekolah dan rumahnya.Prinsip tersebut dipengaruhi oleh dua teori besar dalam ilmu kebahasaan yaitu teori Strukturalis yang mengatakan bahwa Siswa mempelajari bahasa dengan cara memberikan respon dalam praktik latihan, kegiatan berbahasa dan penguatan (Aziz, 2010, pp.2021) dan Behavioris yang mengatakan bahwa Latihan bahasa secara terus menerus agar siswa memiliki keterampilan dan kebiasaan berbahasa (Iskandarwassid, 2009, p.78). Kedua teori besar dari Strukturalis dan Behaviouris itu diteruskan oleh Michigan University dengan pola pembelajaran ASTF yang berprinsip bahwa Pembelajaran bahasa adalah suatu proses pemerolehan serangkaian kebiasaan berbahasa (Brown, 2001, pp.22-23). Selain itu, prinsip tersebut juga secara implisit tertuang dalam Pedoman Pembelajaran Bahasa Inggris di Sekolah Dasar yang diterbitkan oleh Depdiknas (Depdiknas, 2008, p.21).

Sebagai satu-satunya satuan pendidikan tingkat dasar berstatus RSBI di Kota Banjarbaru, SDN Idaman RSBI mempunyai tanggung jawab untuk memenuhi standar nasional pendidikan dan menggunakan Bahasa Inggris sebagai bahasa pengantar dalam proses pembelajaran. Sementara, tindak evaluasi berbasis riset belum pernah dilakukan baik oleh kalangan peneliti akademis, evaluator maupun tenaga pendidik dari lingkungan SDN Idaman RSBI Banjarbaru itu sendiri. Padahal seperti 
telah diuraikan sebelumnya, evaluasi dalam pendidikan mempunyai urgensi bukan hanya sebagai bagian dari amanat undang-undang akan tetapi juga sebagai bahan masukan pembelajaran yang dilaksanakan. Apabila tidak dilakukan evaluasi terhadap proses penerapan Bahasa Inggris sebagai bahasa pengantar dalam proses pembelajaran di SDN Idaman RSBI, maka tidak akan ada data tentang bagaimana hal ini dijalankan dan bagaimana kesesuaian antara penerapan tersebut dengan standar yang sudah ditentukan. Penelitian ini diharapkan mampu mengevaluasi penerapan Bahasa Inggris sebagai bahasa pengantar dalam proses pembelajaran di SDN Idaman RSBI pada tahun 2012/2013.

\section{Metode}

\section{Jenis Penelitian}

Evaluasi secara singkat dapat didefinisikan sebagai proses mengumpulkan informasi untuk mengetahui pencapaian belajar kelas atau kelompok. Ditinjau dari cakupannya, evaluasi bersifat makro dan mikro. Evaluasi makro cenderung menggunakan sampel dalam menelaah suatu program dan dampaknya, sasarannya biasanya adalah program pendidikan. Sedangkan evaluasi mikro biasanya digunakan pada tingkat kelas, khususnya untuk mengetahui pencapaian belajar peserta didik (Djemari Mardapi, 2008, pp.8-11). Penelitian ini menggunakan model Discrepancy (Kesenjangan) yang dikembangkan oleh Provus. Kesenjangan program adalah suatu keadaan antara yang diharapkan dalam suatu program dengan kondisi yang dihasilkan dalam pelaksanaannya. Model ini dipilih karena penelitian ini bertujuan untuk mengetahui tingkat kesesuaian antara standar yang sudah ditentukan dengan kondisi aktual dari pelaksanaan program tersebut. Selain itu, model Discrepancy ini dianggap sangat sesuai untuk mengevaluasi penerapan Bahasa Inggris sebagai bahasa pengantar dalam proses pembelajaran di SDN Idaman RSBI Banjarbaru berdasarkan standar yang ada dalam buku Pedoman Pembelajaran Bahasa Inggris Untuk Sekolah Dasar 2008 yang diterbitkan oleh Depdiknas.

\section{Waktu dan Tempat Penelitian}

Penelitian ini secara keseluruhan dilaksanakan pada bulan Oktober 2011 sampai Juni 2012. Aktivitas pengumpulan data pada saat SDN Idaman RSBI Kota Banjarbaru me- masuki semester ganjil tahun ajaran 2012/ 2103. Tempat penelitian adalah SDN Idaman RSBI Kota Banjarbaru yang beralamat di Jalan R.O. Ulin, Kecamatan Banjarbaru Selatan, Kota Banjarbaru. Pemilihan lokasi ini didasarkan pada beberapa pertimbangan, antara lain: (1) SDN Idaman RSBI merupakan satu-satunya Sekolah Dasar dengan status Rintisan Sekolah Bertaraf Internasional yang ada di kota Banjarbaru; (2) letak sekolah ini yang strategis dan berdekatan dengan tempat tinggal peneliti sehingga memudahkan peneliti lebih sering terjun ke lapangan karena sudah mengenal lokasi dengan baik; dan (3) belum pernah diadakan penelitian yang serupa di sekolah ini.

\section{Target/Subjek Penelitian}

Subjek dalam penelitian ini adalah Kepala Sekolah (sekunder) dan guru (primer) SDN Idaman RSBI Banjarbaru. Sementara itu, objek dalam penelitian ini adalah penerapan Bahasa Inggris sebagai bahasa pengantar dalam proses pembelajaran di SDN Idaman RSBI Kota Banjarbaru.

\section{Prosedur Penelitian}

Dalam penelitian ini, data dikumpulkan untuk selanjutnya ditelaah dan disajikan kembali dengan tujuan mengambarkan kondisi riil dari program yang diteliti. Sasaran dari penelitian model ini adalah tersedianya informasi tentang kesenjangan antara baku (standard) yang sudah ditentukan dari Pedoman Pembelajaran Bahasa Inggris untuk SD Depdiknas 2008 dengan kondisi (performance) sesungguhnya dari penerapan Bahasa Inggris sebagai bahasa pengantar dalam proses pembelajaran di SDN Idaman RSBI Banjarbaru, sehingga didapat informasi tentang kesenjangan antara kedua hal tersebut. Adapun kesenjangan yang akan dicari dalam penelitian ini adalah kesenjangan dari aspek tujuan, metode dan sistem penilaian.

\section{Data, Instrumen dan Teknik Pengumpulan} Data

Dalam pengumpulan data, teknik yang dipakai adalah observasi, wawancara dan dokumentasi dengan memakai instrumen pengumpul data yaitu panduan observasi, panduan wawancara dan alat perekam audio dan/ atau visual. Observasi yang dilakukan adalah observasi terhadap subjek penelitian dan halhal yang dianggap relevan sehingga dapat memberikan data terhadap hasil penelitian. 
Tujuan observasi adalah mendeskripsikan setting yang di pelajari, aktivitas-aktivitas yang berlangsung, pihak-pihak yang terlibat dalam aktivitas, dan makna kejadian dilihat dari perspektif mereka yang terlibat dalam kejadian yang diamati tersebut. Dalam wawancara, pengumpulan data dilengkapi pedoman wawancara yang mencantumkan isu-isu yang harus diliput tanpa menentukan urutan pertanyaan, akan tetapi secara eksplisit merujuk pada standar yang dipakai untuk menentukan pengukuran yaitu Pedoman Pembelajaran Bahasa Inggris di SD Depdiknas 2008. Pedoman wawancara digunakan sebagai daftar aspek-aspek apa yang harus di bahas, juga menjadi dasar (check list) apakah aspek-aspek relevan tersebut telah dibahas atau ditanyakan. Dalam penelitian ini yang diwawancarai adalah Kepala Sekolah dan guru. Kepala sekolah dalam hal ini adalah pembuat dan penanggung jawab program sekolah, sementara guru sebagai pelaksana program dalam kegiatan pembelajaran. Keduanya juga berfungsi sebagai triangulasi data untuk masing-masing informasi yang diberikan oleh kedua pihak yang bersangkutan. Sementara dokumentasi digunakan untuk pengumpulan data yang berkaitan dengan kondisi umum sarana/prasarana penunjang kegiatan belajar SDN Idaman RSBI, kegiatan belajar dalam kelas, perangkat/bahan ajar guru dan dokumen-dokumen lain yang terkait dengan penerapan Bahasa Inggris sebagai bahasa pengantar dalam proses pembelajaran di SDN Idaman RSBI.

\section{Teknik Analisa Data}

Analisis data dalam penelitian ini dilaksanakan dengan pendekatan kualitatif, dilakukan pada saat pengumpulan data berlangsung, dan setelah selesai pengumpulan data dalam periode tertentu. Pada saat wawancara, peneliti sudah melakukan analisis terhadap jawaban yang diwawancarai. Bila jawaban yang diwawancarai setelah dianalisis terasa belum memuaskan, maka peneliti akan melanjutkan pertanyaan lagi sampai tahap tertentu hingga diperoleh data yang dianggap kredibel.

\section{Hasil Penelitian dan Pembahasan}

Hasil Penelitian

Penelitian ini memberikan informasi tentang bagaimana penerapan Bahasa Inggris sebagai bahasa pengantar dalam proses pembelajaran di SDN Idaman RSBI Banjarbaru dan bagaimana kesenjangan antara penerapan tersebut dengan standar yang ditentukan dalam Pedoman Pembelajaran Bahasa Inggris di SD Depdiknas 2008. Berikut disajikan berbagai temuan terkait subjek penelitian yang dikembangkan dalam pertanyaan penelitian.

Tujuan Penerapan Bahasa Inggris sebagai Bahasa Pengantar dalam Proses Pembelajaran di SDN Idaman RSBI Banjarbaru

Pengumpulan data tentang tujuan penerapan Bahasa Inggris sebagai bahasa pengantar dalam proses pembelajaran di SDN Idaman RSBI Banjarbaru menggunakan metode wawancara mendalam terhadap 8 orang guru SDN Idaman RSBI Banjarbaru sebagai informan dan 1 orang Kepala Sekolah SDN Idaman RSBI Banjarbaru yang notabene bertindak sebagai key informan. Dari hasil wawancara tersebut didapatkan hasil sebagai berikut

Penerapan Bahasa Inggris sebagai bahasa pengantar dalam proses pembelajaran di SDN Idaman RSBI Banjarbaru tidak secara spesifik ditujukan untuk menumbuhkan rasa senang siswa terhadap Bahasa Inggris tetapi lebih ke arah mengenalkan Bahasa Inggris ke siswa

Penerapan Bahasa Inggris sebagai bahasa pengantar dalam proses pembelajaran di SDN Idaman RSBI Banjarbaru tidak bertujuan untuk menumbuhkan rasa percaya diri siswa dalam penggunaan Bahasa Inggris secara lisan maupun tertulis

Penerapan Bahasa Inggris sebagai bahasa pengantar dalam proses pembelajaran di SDN Idaman RSBI Banjarbaru bertujuan untuk meningkatkan kemampuan siswa dalam bahasa lisan melalui pengembangan keterampilan berbahasa

Penerapan Bahasa Inggris sebagai bahasa pengantar dalam proses pembelajaran di SDN Idaman RSBI Banjarbaru tidak ditujukan untuk meningkatkan kemampuan siswa dalam bahasa tulisan melalui pengembangan keterampilan berbahasa

Penerapan Bahasa Inggris sebagai bahasa pengantar dalam proses pembelajaran di SDN Idaman RSBI Banjarbaru bertujuan untuk membuat siswa lebih memahami bahwa Bahasa Inggris adalah alat komunikasi 
Metode Penerapan Bahasa Inggris sebagai Bahasa Pengantar dalam Proses Pembelajaran di SDN Idaman RSBI Banjarbaru

Teknik yang digunakan peneliti untuk mengetahui metode penerapan Bahasa Inggris sebagai bahasa pengantar dalam proses pembelajaran di SDN Idaman RSBI Banjarbaru dengan menggunakan checklist observasi. Observasi dilaksanakan sebanyak 5 kali pada tingkatan kelas yang berbeda. Berdasarkan hasil observasi dapat dideskripsikan mengenai metode penerapan Bahasa Inggris sebagai bahasa pengantar dalam proses pembelajaran di SDN Idaman RSBI Banjarbaru yang dilakukan guru di kelas (informan). Dari 14 indikator pembelajaran diketahui bahwa hanya 5 indikator yang terpenuhi oleh sebagian besar informan dalam pembelajaran di kelas dengan prosentase lebih dari 50\% yaitu sebagai berikut : Guru memberikan instruksi dalam Bahasa Inggris dengan jelas dan mudah dipahami oleh siswa; Guru menggunakan kata-kata Bahasa Inggris yang dimengerti oleh siswa; Menggunakan sumber berbahasa Inggris/Bilingual dalam pembelajaran; Menciptakan hubungan yang positif dengan peserta didik dengan memberikan pujian dalam Bahasa Inggris yang sederhana ; Menciptakan hubungan yang akrab dengan peserta didik (misal, menyapa siswa dengan kalimat sapaan berbahasa Inggris)

Sedangkan indikator lain yang berhubungan dengan penggunaan bahasa Inggris baik mengenai vocabulary, penulisan, feedback, dan lain-lain masih belum terpenuhi dalam proses pembelajaran guru di kelas.

Dalam proses pembelajaran termasuk diantaranya pengantar pembelajaran, seorang guru setidaknya mengacu pada perencanaan awal yang seringkali disebut Rencana Pelaksanaan Pembelajaran. RPP ini dijabarkan dari silabus, dan ini merupakan skenario proses pembelajaran untuk mengarahkan kegiatan-kegiatan belajar siswa untuk mencapai kompetensi dasar serta untuk menentukan metode pembelajaran. Dalam mendukung pelaksanaan metode penerapan bahasa inggris sebagai bahasa pengantar, peneliti melakukan observasi pada Rencana Pelaksanaan Pembelajaran dengan teknik checklist pada komponen RPP SDN Idaman RSBI Banjarbaru, dimana hasil observasi terlihat bahwa dari keseluruhan komponen muatan RPP sebanyak tujuh komponen tidak ditemui muatan penerapan Bahasa Inggrisnya jadi dapat disimpulkan bahwa penerap- an Bahasa Inggris sebagai bahasa pengantar di SDN Idaman RSBI Banjarbaru belum terkandung dalam RPP SDN Idaman RSBI Banjarbaru.

Tidak ditemukannya muatan Bahasa Inggris dalam keseluruhan komponen RPP menunjukkan bahwa sebenarnya memang penerapan bahasa Inggris sebagai bahasa pengantar tidak dimasukkan dalam perencanaan awal pembelajaran sehingga tidak heran ketika metode pelaksanaannya juga tidak terpenuhi secara keseluruhan.

Sistem Penilaian Penerapan Bahasa Inggris sebagai Bahasa Pengantar dalam Proses Pembelajaran di SDN Idaman RSBI Banjar-baru

Untuk mengetahui sistem penilaiannya, peneliti menggunakan teknik wawancara terhadap informan dan key informan dengan hasil wawancara menunjukkan bahwa selama ini tidak pernah dilakukan sistem penilaian terkait dengan penerapan Bahasa Inggris sebagai bahasa pengantar di SDN Idaman RSBI Banjarbaru. Hasil wawancara menunjukkan bahwa sampai penelitian ini dilaksanakan, belum pernah ada penilaian yang terkait dengan penerapan Bahasa Inggris sebagai bahasa pengantar dalam proses pembelajaran di SDN Idaman RSBI Banjarbaru.

Pembahasan

Berdasarkan hasil evaluasi tujuan yang peneliti lakukan dengan metode wawancara diketahui bahwa secara keseluruhan penerapan Bahasa Inggris sebagai bahasa pengantar di SDN Idaman RSBI Banjarbaru belum mempunyai rumusan tujuan yang jelas dan sesuai dengan yang tercantum pada Pedoman Pembelajaran Bahasa Inggris di SD Depdiknas 2008. Dari ke empat standar tujuan yang ditetapkan oleh Depdiknas diatas hanya dua tujuan yang dirumuskan dalam penerapan Bahasa Inggris sebagai bahasa pengantar dalam proses pembelajaran di SDN Idaman RSBI Banjarbaru yaitu meningkatkan kompetensi komunikasi siswa dalam bahasa lisan pengembangan keterampilan berbahasa dan membuat siswa lebih memahami bahwa Bahasa Inggris adalah alat komunikasi. Walaupun sebagai key informan Kepala Sekolah SDN Idaman RSBI Banjarbaru mengiyakan keseluruhan indikator tujuan yang peneliti tanyakan tetapi dalam kenyataanya key informan belum bisa menampilkan bukti dokumen terkait jawaban yang diberikan. Sebenarnya kesenjangan tujuan ini mut- 
lak bukan karena penerapan Bahasa Inggris sebagai bahasa pengantar di SDN Idaman RSBI Banjarbaru dari awal yang berbeda dengan tujuan yang ditetapkan Depdiknas, tetapi lebih kearah personalnya yang belum memahami dokumentasi yang sudah ada selama ini. Hal ini terlihat dari buku kurikulum SDN Idaman RSBI Banjarbaru yang di dalamnya menyebutkan keseluruhan standar misi dan tujuan kegiatan berbasis keunggulan global.

Sesuai dengan evaluasi peneliti mengenai metode penerapan Bahasa Inggris sebagai bahasa pengantar dalam proses pembelajaran di SDN Idaman RSBI Banjarbaru dengan analisis checklist observasi didapatkan hasil bahwa penerapan bahasa Inggris hanya sebatas pembuka, kalimat perintah sederhana dan penutup tanpa memberikan kesempatan siswa untuk melakukan feed back terhadap kalimat guru melalui vocabulary bahasa Inggris juga. Dari keseluruhan standart metode untuk merealisasikan tujuan pembelajaran Bahasa Inggris di SDN Idaman RSBI Banjarbaru yaitu perangsangan aktivitas siswa untuk SD yang ditetapkan Depdiknas 2008 di atas hanya satu yang terealisasikan yaitu siswa diberikan kesempatan membangun sikap positif terhadap bahasa dan belajar bahasa asing. Keadaan itu secara tidak langsung menimbulkan banyak kesenjangan antara realisasi dengan standar yang telah ditetapkan Depdiknas 2008 tentang metode untuk merealisasikan tujuan pembelajaran bahasa Inggris. Kesenjangan yang paling mencolok adalah respon instruksi oleh siswa yang hanya dilakukan dalam bentuk tindakan tanpa verbal, siswa kurang bisa melakukan percakapan transaksional dan interpersonal karena tidak diberikannya kesempatan, siswa kurang terbiasa membaca teks pendek karena siswa hanya diberikan kesempatan untuk bertindak tanpa mengeluarkan verbal.

Kesenjangan yang timbul dalam metode penerapan Bahasa Inggris sebagai bahasa pengantar di SDN Idaman RSBI Banjarbaru menurut analisa peneliti disebabkan karena guru sebagai pelaku pembelajaran kurang memahami tujuan penerapan bahasa Inggris itu sendiri sehingga ketika tujuannya tidak sesuai maka secara otomatis metode/langkah yang digunakan untuk mencapai tujuan juga kurang sesuai. Disamping itu hal lain yang mungkin mempengaruhi kesenjangan metode adalah kemampun guru dalam berbahasa Inggris baik lisan maupun tulisan. Hal ini sangat mempengaruhi karena disini guru bertindak sebagai master yang memberikan ilmunya kepada siswa jadi ketika guru kurang paham dan kurang mengerti maka transfer ilmu yang diberikan termasuk penerapan berbahasa Inggris di dalamnya juga terbatas sesuai dengan kemampuan guru.

Evaluasi peneliti terkait dengan sistem penilaian dalam penerapan Bahasa Inggris sebagai bahasa pengantar dalam proses pembelajaran di SDN Idaman RSBI Banjarbaru menunjukkan bahwa selama ini tidak pernah dilakukannya sistem penilaian. Perbedaan keadaan dengan kurikulum yang ada terjadi dikarenakan masing-masing pihak belum memahami secara benar apa isi kurikulum yang sebenarnya menjadi pedoman pembelajaran baik akademik maupun non akademik, sehingga guru hanya berpedoman pada pembelajaran praktek saja tanpa meninjau lebih lanjut mengenai pedoman/peraturan yang mengatur sebelumnya.

\section{Simpulan dan Saran}

Simpulan

Penerapan Bahasa Inggris sebagai bahasa pengantar dalam proses pembelajaran di SDN Idaman RSBI Banjarbaru:

Kepala Sekolah SDN Idaman RSBI menyatakan bahwa tujuan penerapan Bahasa Inggris sudah sesuai standar, namun demikian hasil penelitian menunjukkan bukti sebaliknya.

Metode penerapan Bahasa Inggris sebagai bahasa pengantar di SDN Idaman RSBI hanya sebatas pada opening dan closing activities, instruksi sederhana, pemberian pujian dan sapaan, sedangkan bagian inti pembelajaran masih menggunakan Bahasa Indonesia.

Sistem penilaian penerapan Bahasa Inggris sebagai bahasa pengantar di SDN Idaman Banjarbaru sampai penelitian ini dilaksanakan belum pernah dilakukan.

Kesesuaian penerapan penerapan $\mathrm{Ba}-$ hasa Inggris sebagai bahasa pengantar dalam proses pembelajaran di SDN Idaman RSBI Banjarbaru dengan Pedoman Pembelajaran Bahasa Inggris di Sekolah Dasar Tahun 2008 yang diterbitkan oleh Depdiknas:

Tujuan penerapan belum sesuai dengan tujuan yang tercantum Pedoman Pembelajaran Bahasa Inggris di SD Depdiknas 2008.

Metode penerapan belum sesuai dengan keseluruhan prinsip yang tercantum da- 
lam buku Pedoman Pembelajaran Bahasa Inggris di SD Depdiknas 2008.

Sistem penilaian belum sesuai dengan keseluruhan prinsip yang tercantum dalam buku Pedoman Pembelajaran Bahasa Inggris di SD Depdiknas 2008.

Saran

Saran penelitian ini adalah agar SDN Idaman RSBI Banjarbaru merumuskan tujuan penerapan Bahasa Inggris sebagai bahasa pengantar dalam proses pembelajaran secara jelas sesuai dengan Pedoman Pembelajaran Bahasa Inggris di SD Depdiknas 2008. Hal ini akan membuat metode yang akan dipakai untuk meraih tujuan menjadi terarah dan keberhasilan program bisa diukur. Selanjutnya, para guru juga dihimbau untuk meningkatkan kemampuan Bahasa Inggrisnya agar dalam pelaksanaan penerapan Bahasa Inggris sebagai bahasa pengantar dalam proses pembelajaran tidak mengalami kendala teknis kebahasaan.

\section{Daftar Pustaka}

Brown, H. D. (2001). Teaching by principle: an interactive approach to language pedagogy. Longman. New York.

Departemen Pendidikan Nasional. (2008). Pedoman pembelajaran bahasa inggris di sekolah dasar. Jakarta.

Fachrurrozi, Aziz. (2010). Pembelajaran bahasa asing metode tradisional dan kontemporer. Jakarta: Bania Publishing

Iskandarwassid \& Dadang Sunendar. (2009). Strategi pembelajaran bahasa. Bandung: Pasca Sarjana UPI \& PT. Remaja Rosdakarya

Mardapi, Djemari (2008). Teknik Penyusunan instrumen tes dan non tes. Yogyakarta: Mitra Cendekia Press. 